\title{
The Negative Impacts of Commercial Concealment on the Performance of Small Businesses in Jeddah Province in Saudi Arabia
}

\author{
Nayef Al-Ghamri ${ }^{1}$ \\ ${ }^{1}$ Faculty of Economics and Administration, King Abdulaziz University, Jeddah, Saudi Arabia \\ Correspondence: Nayef Al-Ghamri, Faculty of Economics and Administration, King Abdulaziz University, \\ Jeddah, Saudi Arabia. Tel: 966-561-364-017. E-mail: nayef.alghamri@gamil.com
}

Received: June 6, 2016

Accepted: June 21, 2016

Online Published: July 25, 2016

doi:10.5539/ijef.v8n8p124

URL: http://dx.doi.org/10.5539/ijef.v8n8p124

\begin{abstract}
The commercial concealment phenomenon leads to negative economic, security and social consequences. It has been linked to several other phenomena such as money laundering operations and the violation of residence and work regulations by foreign workers who have been deported several times from the country due to their illegal entry. The trading practice by foreigners has been widespread for two main reasons: first, due to the availability of jobs; second, the Kingdom of Saudi Arabia is the shrine for many Muslims, especially after the Umrah (mini religious pilgrimage ceremony) or Hajj seasons. These reasons have contributed to the presence of a large number of foreigners who engage in commercial concealment activities with the help of a Saudi citizen. Such practices have contributed negatively towards both, the economy and the society, noting that the number of those foreigners is on the rise. Aggravating this situation, foreigners conceal each other's practices by hiring other foreigners in their businesses and not Saudi citizens. More light has been shed on the commercial concealment issue, whereby, citizens, the media and authorities have altogether started to combat this phenomenon. It is gaining more attention especially after the spread of many security-related crimes that are constantly published in daily newspapers. Moreover, commercial concealment played a role in the increase of the unemployment rate among young people and the control of foreigners of many commercial and services businesses in which small businesses occupy a large portion. The importance of this research study is demonstrated in its focus on the commercial concealment phenomenon and its negative impacts on the State. This particular phenomenon gravely harms the economy and inflicts damage on the society through the spread of drugs, theft and other crimes. The current research addresses this phenomenon relying on the application of a positivistic (scientific) approach to study, with a deductive approach by analyzing and reaching appropriate solutions or answers to this phenomenon. The research explores the reasons behind commercial concealment, its economic impact and defines the means to combat it by identifying the best local, international methods and regulations to combat the commercial concealment crime. To identify the various aspects related to the reasons behind commercial concealment, information and data relevant to the research topic was collected from the private sector, official bodies, citizens and other related sectors of the society. Thus, this research study followed an explanatory nonexperimental research design (Belli, 2008; Cook and Cook, 2008; Johnson, 2001) via a survey which was distributed to a 100 randomly selected sample. The IBM SPSS Statistics 23 Package for the Social Sciences (SPSS $®$ ) software was used to analyze the collected data. The research drew up some proposed recommendations to combat the commercial concealment phenomenon based on the results of the analysis of questionnaires and the study of laws, regulations and relevant references.
\end{abstract}

Keywords: commercial concealment, survey, money laundering, small businesses, human trafficking Saudi Arabia

\section{Introduction}

\subsection{Background into the Problem}

Saudi Arabia is gifted with its natural resources and its strategical geographical location which have been the source for attracting a lot of people around the world. The high level of salaries and the economic prosperity have served as motivating factors for many workers to abandon their original work contract and practice trade activities which generate huge profits. This occurs because some sponsors (known in Arabic as the "Kafeel" system) are tolerant or probably because some foreigners pay to their sponsors an amount of money or a small 
percentage of their income in exchange of using the sponsor's name to engage in a private business. Such an action has resulted in many economic and social problems not to mention a continuous increase in crime rates. Since Saudi Arabia is neighbor to Islamic countries with a high population density and modest economic levels, such as Pakistan, Bangladesh, Yemen, Egypt and others, it has been targeted by countless people who wish to work there. Those foreigners enter the country initially in a legal way for the purpose of visit but extend their stay after the expiry of their legal residence period. Others apply for a visa to work for a sponsor but escape their original sponsor and work for their own account (Kinsawi, 2008). It should be noted, however, that $52 \%$ of those people who belong to this category escape their sponsors and work in business activities under commercial concealment (Beshity, 2008).

\subsection{Definition of Commercial Concealment}

Commercial concealment is defined as enabling a non-Saudi to invest or engage in any commercial activity for the foreigner's account or to participate with other prohibited party/parties in exercising such activities or those who are prevented to practice business by the foreign capital investment system or other regulations and instructions. A citizen shall be deemed to be committing an act of concealment if he/she enables a non-Saudi to use the citizen's name, license or commercial registration. A foreigner is deemed to be committing an act of commercial concealment if he/she has obtained a foreign investment license and has enabled another foreigner to work for his/her account as opposed to the foreign capital investment system. Commercial concealment leads the foreigner to evade payment of fees imposed by the foreign investment system by holding a simulated contract including salary and remuneration (Al-Abdulali, 2003).

\subsection{The Research Problem}

Commercial concealment is considered one of the major challenges facing many government officials, economic thinkers and Saudi citizens in our modern age. This overriding challenge has been, and continues to be, dominating the Saudi economy for a long period of time. It has had devastating consequences on all aspects of the economy including unemployment, external transfer of funds, balance of payments deficit, and foreigners' control of products, services and other markets. Its disastrous consequences have also outreached several social aspects, such as the spread of forbidden international commodities including drugs, as well as security aspects such as theft, murder and finally its influence in changing the demographic composition. In spite of these terrible consequences, there is a daily rise in the number of illegal and undocumented workers who are engaged in commercial concealment activities.

The serious nature of this problem is underlined by the grave consequences it entails on the Saudi society. Hence, it is of utter importance that the whole society act together to confront this problem. As long as Saudi Arabia continues to be an attractive location for many people from poor surrounding Asian countries suffering from very high rate of unemployment, where workers accept to do any type of work for money regardless of the quality or the standard of the business, and as long as Saudi Arabia enjoys great wealth, the problem will continue for years to come. Thus, the research problem addresses this area of concern which requires studying its causes, finding solutions to combat it and eventually eliminate the problem.

\subsection{The Research Hypothesis}

The first hypothesis: There is a statistically significant relationship between commercial concealment and the performance of small businesses.

The second hypothesis: There is a statistically significant relationship between commercial concealment and the avoidance of starting up small businesses.

The third hypothesis: There is a direct correlation of statistical significance between lack of strict law enforcements and the spread of commercial concealment.

The fourth hypothesis: There is a direct correlation of statistical significance between the citizen's awareness and the spread of commercial concealment.

The fifth hypothesis: There is a direct correlation of statistical significance between economic and financial problems on one hand and commercial concealment on the other hand.

The sixth hypothesis: There is a direct correlation of statistical significance between social problems and commercial concealment.

The seventh hypothesis: There is a direct correlation of statistical significance for the role of official bodies in combating commercial concealment.

The eighth hypothesis: There is a direct correlation of statistical significance for the role of the private sector, 
including commercial banks, in combating commercial concealment.

The ninth hypothesis: There is a direct correlation of statistical significance between the nationalities engaged in commercial concealment activities and the type of professions they control.

The tenth hypothesis: There are advantages for commercial concealment which positively influence the development, construction, commercial and services sectors.

\subsection{Importance of the Research}

The importance of this research is derived from the consequences that follow commercial concealment activities which put economic burdens and drain the Saudi economy. Several problems emerged including commercial fraud, counterfeit goods and even counterfeit medications that may threaten the lives of individuals; in addition to social problems such as theft and drugs. In this context, there is a dire need to devote attention to this subject which has evoked deep concerns of the business community and the society in general. The research is of crucial importance in making the best use of the solutions and recommendations it draws up and is particularly valuable for its immediate benefits to relevant fields.

\subsection{Expected Results and the Means to Take Advantage of Them}

The findings and recommendations of this research are expected to provide a diagnosis and an attempt to measure the multiple dimensions of the phenomenon related to the violation of residence and work systems. It also aims to study the factors, internal and external causes of the phenomenon and draw up applicable procedural mechanisms based on a short-term and a long-term realistic plan to combat this problem. It is also expected to benefit from the findings of this research by gradually combating this phenomenon and raising public awareness for citizens and legal residents to expose violators. It is also possible to take advantage of the research findings by following the points highlighted in the recommendations of the research.

\subsection{Research Aims and Objectives}

- Identify the reasons that have led foreign workers to engage in commercial concealment practices and the citizens' role in the concealment of foreign workers' activities; as well as the official bodies responsible for combating commercial concealment.

- Identify the economic, social and security reasons for commercial concealment.

- Identify foreign nationalities engaged in commercial concealment and the type of activities they practice.

- Identify the role of official bodies responsible for combating commercial concealment.

- Draw up conclusions, solutions and recommendations for combating commercial concealment practices.

\subsection{Research Methodology}

A descriptive approach has been undertaken in this study since which relies on analyzing the real-life issue which describes the commercial concealment phenomenon. The approach has been used to study the phenomenon in terms of quantitative (mainly) and qualitative research, to a lesser extent; then analyze and interpret the answers to the questionnaire, in consistency with the actual data of the phenomenon.

\subsubsection{The Population of the Study}

The population from which the respondents were selected from included Saudi citizens, foreign workers and officials working in Saudi State bodies. Other members of the population included businessmen, owners of leased buildings and exhibitions and some university students.

\subsubsection{Research Sample}

A simple random sample of individuals was selected from the population of the study.

\subsubsection{Scope of the Study}

The Locale of the Study: This study is limited to the Jeddah Province in Saudi Arabia.

Limits of Time: This study is conducted within four months according to the following phases:

First Phase: Two months were dedicated for the theoretical part of the Research.

Second Phase: Two months were dedicated for the practical part of the research.

\subsubsection{Research Tools}

The required data for the study shall be collected using the following tools: 
- A survey was distributed to the sample of respondents including citizens, foreign workers and officials working in State bodies.

- Sources and references related to the subject of research.

- Rules and regulations of ministries and departments related to the research.

- Studies, research and reports published in newspapers and magazines.

1.8.5 Statistical Methods

The gathered data was organized and entered into an MS Excel ${ }^{\circledR}$ sheet which was later transferred to 'The Statistical Package for the Social Sciences' (SPSS ${ }^{\circledR}$ ) software.

\section{Review of Literature}

\subsection{The Impacts of Commercial Concealment}

\subsubsection{First: Economic Impacts}

Commercial concealment leads to the transfer of funds out of the Kingdom of Saudi Arabia, ranking the world's second-largest source of remittances reaching up to US\$37 billion in 2015 (Arab News, 2015). Therefore, the impacts of commercial concealment on the Saudi economy may be similar to a growing malignant tumor (Al-Salem, 2011) and lead to unfair competition (Iqbal, 2011), tax evasion, decline of quality of goods and services (Al-Kaaby, 2014), spread of counterfeit medicinal drugs (Banier, 2013; Fenoff \& Wilson, 2009) which cause economic instability and damage users' health whereby strict laws should be enforced to prevent its spread (Wertheimer \& Santella, 2010) as well as spread of counterfeit products of popular brands (Commuri, 2009; Penz, 2005), manipulation of prices (Al-Mansour, 2003), loss of investment opportunities in private businesses for Saudis as a result of foreigners' monopoly of small businesses (Sabry, 2015), loss of job opportunities for young people since small and family businesses employ their family members and young people, whereas the presence of a large number of foreign workers puts a burden cost on the State since medical treatment is generally free in Saudi Arabia. Some services provided by a lot of foreigners are of low-quality because those service providers come from developing countries. Furthermore, lack of cleanliness and hygiene in restaurants managed by workers of certain nationalities can be noticed. The heavy usage of public utilities, health and transportation services result in traffic volumes on public roads (Rabiean, 2016). In addition to the appearance of dummy corporations that deal with illegal and undocumented workers (Ayban, 2011).

Many small businesses are registered in the name of a Saudi citizen but are actually owned by a foreigner. In such a case, a Saudi can request to recruit foreign workers in his corporation (Al-Zahrani, 2012). Such an action increases the arrival of foreign labor because the size of small businesses exceeds $85 \%$ of the total registered businesses (Al-Ghamri, 2009).

Commercial concealment is considered one of the pillars of shadow economy and money laundering (Al-Khamisi, 2013).

In spite of the previous shortfalls, some advantages for commercial concealment can still be noticed. We are unable to close the shops abruptly because this will lead to failure to take appropriate action or make progress, literally a "paralysis" in the services and business operations. In addition, foreign skilled workers, in some situations, stimulate economic growth (Robins, 2014) and may be more enthusiastic and determined than the national labor force (Kirkup \& Dominiczak, 2013) and are required even in times of economic recession (Kashiwazaki, 2002).

Security risks such as theft, human trafficking and prostitution (Al-Amari, 2015), rape and murder.

The drug problem has become a global phenomenon which shall not disappear in the near future (Wertheimer \& Santella, 2005). The phenomenon has spread in the Arab Gulf States, especially in the United Arab Emirates (Robins, 2014). The value of illicit drug trade in Saudi Arabia is estimated for $\$ 5.5$ billion annually, while in Britain it is about $£ 10.7$ billion - equivalent to $\$ 16.5$ billion (Perry, 2015). The majority of drugs in Saudi Arabia come from a number of sources as Yemen, Syria and Pakistan (Al-Mansour et al., 2012). Afghanistan, likewise, has a share since its opium economy makes up around $14 \%$ of the country's GDP, amounting to $\$ 3$ billion annually generated by drug trade (Goodman, 2015).

Many individuals practice medical professionals through fraudulent certificates leading to the death of 2,500 persons, in some cases, due to medical errors arising from commercial concealment where a foreign worker employs other workers of the same nationality in concealed clinics (Al-Shayaa, 2010). Commercial concealment is common in dental clinics controlled by foreigners (Rasooldeen, 2015).

The economic and health implications of infectious diseases transmitted through workers from poor countries or 
due to failure to provide health insurance for those workers, lack of foreign workers' awareness of the medical system in Saudi Arabia or lack of providing adequate health care for foreign workers by some hospital staff (Anand , 2013).

\subsubsection{Second: Social Impacts}

The large numbers of foreign males living without their spouses or families and the spread of culturally odd views in the conservative society of Saudi Arabia, may lead to the spread of immoral practices and prostitution among foreign female workers as a result of alluring financial temptations.

The spread of unemployment rates among Saudis and its impact on family problems, where a wife may be forced to look for any job with a modest salary, stick to this position and neglect her household affairs and husband.

Foreign workers stay for long periods in Saudi Arabia and control commercial activities, especially workers coming from underdeveloped countries. This matter may form a barrier to the entry of new skilled workforce and prevent the advent of modern technology (Al-Shamasy, 2006).

\subsection{The Reasons for the Spread of Commercial Concealment Practices}

Lack of awareness among citizens, whether intentionally or unintentionally. A citizen's tolerance in dealing with a foreigner will lead the later to exploit the citizen through taking advantage of the visa, by which he originally entered into the country, for the purpose of engagement in business activities. For example, if the visa permits a foreign driver to work in Saudi Arabia but the foreigner exploited the visa to engage in other commercial activities, the law has been breached by both the citizen and the foreigner. In a second example, many workers are recruited in Saudi Arabia through Saudi citizens who agree to receive a sum of money from each worker. A third example is the worker's escape from his sponsor (Kafeel) in order to work on his own account. Upon occurrence of such case, the citizen must report to official bodies whereby non-participation in curtailing concealment acts paves the way for many foreigners to run away from their sponsors and engage in private businesses (Al-Amri, 2015). Therefore, it is necessary to develop an entirely new system or develop the sponsorship (Kafeel) system currently existing in Saudi Arabia (Atoui \& Al-Bawardi, 2013).

Many Saudi businessmen are interested in land trade which does not reflect as a value-added measurement in the gross domestic product. Land trading is considered a less risky activity since land is not subject to taxes, has a long period of validity and has a high demand - compared to ready-constructed buildings - due to the high birth rate. Many people are not willing to engage in construction or contracting work due to their lack of experience in fields related to construction, engineering, planning and shortage of financial capacities. Not to mention the inexistence of a mortgage system in Saudi Arabia which reduces the demand for ready-constructed houses. This leads to the failure of a lot of real estate projects and the tendency of many Saudis to trade in lands which does not require any administrative, engineering or accounting expertise and its retention by foreigners including Egyptians and Syrians (Assaf, Srour, \& Hassanain, 2013).

Political instability and unrest in many countries around the world, such as the Syrian crisis, has led hundreds of thousands of Syrians to flee to Saudi Arabia and search for jobs, whether legitimate or illegitimate, regular or irregular jobs.

During the times of economic prosperity, many male citizens apply for commercial registers in the name of their wives, thereby, many Saudi women have commercial registers utilized by foreigners. Financial penalties are imposed on the innocent woman victim, either a wife or a sister, for being involved in commercial concealment practices and most of them are arrested and penalized. The Saudi system does not allow a State official to engage in private business, hence a citizen may recruit a foreigner to manage the business. In almost all cases, the real beneficiary from the business is the foreigner because the distribution of profit is based on a percentage or, sometimes, a lump sum (Rasooldeen, 2015).

A number of Saudis do not have a desire to work at all. About fifty-five thousand Saudis are not interested to practice any type of work and depend on the money they receive from their families (Ekrami, 2016).

Most franchise companies employ foreign workers and the owner is usually a foreigner. They do not correctly apply the franchise regulations but often use a Saudi's name in the commercial register. In such a case, the owner in Saudi Arabia is a foreigner, the workers are foreigners and probably the citizen is only invited to attend the opening ceremony but does not have any real authorities to manage the business.

Commercial concealment practices are often held in small and medium-sized enterprises. Many young people prefer to work in official bodies due to the advantages the State offers such as job stability. However, a foreigner usually lives with a group of single individuals close to the workplace and may often live at his work premises. 
One of the problems facing the combating of commercial concealment is that working hours in official government agencies are during the day hours, while most of the shoppers and family members shop during the evening or at night. Therefore, the monitoring of concealed shops is ineffective due to the absence of inspectors.

When inspectors are present on site, many foreign workers close their shops as they communicate and notify each other via the cellular phone.

Foreign workers engaged in trade activities have been living in the Kingdom for decades while many foreigners have been operating their private businesses long time ago. The Arabian Peninsula has been the center of trade between the north and the south of the hemisphere. The economic boom has further attracted huge numbers of foreigners that even exceed the number of Saudis. This has helped foreigners achieve a form of monopoly over certain professions such as the Yemenis' monopoly of cloth trade, the Turks' monopoly of furnishings and the Egyptians' monopoly of contracting works.

Monthly materialistic and moral benefits to the citizen.

The non-commitment of citizens to attend judiciary court cases.

The idleness of a Saudi citizen (Al-Naqmy, 2013).

A foreigner transfers the profits of his business on a regular basis to his country. If the foreigner is arrested, the funds would have already been transferred or the worker may travel out of the country at any time, leaving behind him the rental of the shop and the purchase invoices for the Saudi sponsor to settle.

Lack of regular inspection especially on specialized professions. Some workers have entered the country to practice plumbing or technical works but after the elapse of a long period of time they become contractors, engineers or doctors. They may also buy some fake certificates and practice professions which generate large amounts of money (Al-Dani, 2013).

Foreigners have been in control of trade and markets for so many years. For example, foreigners control $80 \%$ of the electronic products market (Al-Sharif, 2016) while 50\% of the commercial concealment practices take place in the transport sector in Al Sharqeyya (Eastern) district (Al-Sheeban, 2015). Foreigners help newcomers and preserve the aspects of a Supportive Culture (Handy, 1985) since they prefer teamwork and focus on collectivism, such as Indians and Pakistanis, (Chadha, 1999; Kim, 2008) as opposed to the English ideological belief based on Economic Individualism.

\subsection{Previous Studies}

A study entitled "The relationship between the sponsorship (Kafala) system and concealed trade" by Al-Ruwais (2014) showed that the sponsorship system is the main source for the spread of commercial concealment. Many Saudi citizens took advantage of the sponsorship system in trading in visas. This action shows a lack of awareness among citizens and the dominance of economic aspects over public interest. The study showed that $30 \%$ of foreign workers in Saudi Arabia work for their own private businesses under commercial concealment. The top three nationalities practicing commercial concealment activities are Bengalis at $22.7 \%$, followed by Egyptians at $19 \%$ and Syrians at $14.1 \%$ (Al-Ruwais, 2014). The study also showed that commercial concealment is centered in specific activities including the construction and contracting sectors at $57 \%$, consumer goods at $13.2 \%$, general trade at $12 \%$ while foreigners' control of the ready-made garments trade reached $97.2 \%$. Finally, the study showed that the unemployment rate in Saudi Arabia reached 10.6\%.

A study entitled "A proposal for combating the phenomenon of illegal, undocumented workers and violators of residence and work regulations in Saudi Arabia" by Mahmoud Kisnawi (2008). The study has particularly focused on the violators of regulations more than focusing on the commercial concealment in itself. The study divided the immigration phenomenon, or what is known as illegal immigration, to several categories. These categories are as follows:

Individuals entering the Arab Gulf States are classified to enter through any of the following means:

1) Illegal means;

2) Legal means - but extend their stay after the expiry of their period of residence and are therefore considered illegal residents;

3) A work visa for practicing several professions, such as a driver, a security guard and so forth. But later practice illegal work during their residence period under commercial concealment.

This means that individuals who violate residence and work regulations extend their stay in countries characterized by attractive economic and social factors in search of a better economic status. They violate the law due to 
unfavorable conditions in their countries as unemployment, poverty and high population. Saudi Arabia is one of the countries privileged for attractive factors to live and work given the size of oil wealth and its geographical location amidst poor and highly populated countries. The study showed that there are 15.5 million entrants to the countries of the Gulf Cooperation Council (GCC). The study mentioned that the immigration phenomenon has led to economic, social and security problems which have negatively impacted the Saudi citizen. It also mentioned that the problem still exists and continues to rise annually.

A study by "The Chamber of Commerce and Industry for the Eastern Province in Saudi Arabia". The study focused on commercial concealment and its economic and social impact on Saudi Arabia (Chamber of Commerce, 2010). The study also showed the importance of the role of the Chamber of Commerce and Industry for the Eastern Province in combating commercial concealment and preventing its spread. The study did not point, however, to the impact of commercial concealment on small businesses. Instead, it focused on the political and security implications of commercial concealment on the Saudi society. The impact of around 11 million foreigners on the society is negatively viewed with regards to security aspects such as theft, murder, drug, forgery and influencing the Saudis to feel themselves a minority, in some cases, especially in neighborhoods marked by heavy concentrations of foreign workers. The study also stated that citizens play a major role in the spread of commercial concealment.

A study carried out by Abdul Majid Al-Suhaimi (2011) entitled "Commercial Concealment: Damages and consequences". In this study, the researcher addressed the most important social and economic problems arising from commercial concealment and draws up some recommendations to solve these problems. The research was interested in the definitions of 'commercial concealment' and 'sponsor' (Kafeel) and focused on the legal aspects of commercial concealment. However, it did not link commercial concealment and its impacts to small businesses nor did it provide any in-depth examination of its consequences.

A study conducted in the United Kingdom entitled "The Pakistani Muslim Community in England” (PMCE, 2009). The study focused on the behavioral change in Pakistani workers, men and women alike, over the previous years. Foreign workers were hired for the first time in Britain from Kashmir in the 1950s. Since then, the traditional model of many conservative families, where women stayed at home and men took the primary responsibility for bread winning, have been dramatically transformed. In modern generations, Pakistani women work in all fields alongside men. Although a lot of workers in the 1950s used to transfer money to their families in Pakistan, the situation has completely changed nowadays. This shows that there has been a great connection to the extended large family in the past where a worker used to send money to his mother and father and felt homesick for his country. However, the present generation consider Britain their country, not Pakistan, and the relationship between the worker and his family in Pakistan is almost non-existent. The study also stated that there are still some external remittances to Pakistan from workers in Britain estimated at \$ 273.83 million annually. In the same context, the report stated that the United States ranks the first in terms of workers' remittances to their families estimated at \$ 4.23 billion followed by the Arab Gulf States at $\$ 1.23$ billion. The study also showed that a percentage of the workers' earnings in Britain is invested in the purchase of stock, real estate and development of their own commercial markets. This is a good mechanism to encourage the maintenance of funds inside the UK, increase the demand for real estate and increase internal capital flows rather than the transfer of capital and hard currency out of the country as it is the case in Saudi Arabia.

\subsection{Comment on Previous Studies}

After shedding light on previous studies, it is obvious that most of them have linked commercial concealment with unemployment and its impact on economic, social and security aspects. Most studies on commercial concealment are conducted in the form of a thesis to earn a master's degree. This case is applied in Al-Suhaimi's (2011) research on commercial concealment and other studies in which they all share the same context, namely, the reasons for the spread of commercial concealment, the means and recommendations to combat it. However, none of these studies linked commercial concealment with small businesses. Most of the conducted research focused on the problems caused by foreign labor and is not involved with any aspect related to commercial concealment.

\section{Data Analysis}

In this section, a description of the analysis of the gathered data is given. As mentioned previously, data was collected by means of the survey of the negative effect of commercial concealment on the performance of small businesses in the municipality of Jeddah in Saudi Arabia. Additionally, this section will present the measures taken, including statistical measure, to ensure validity and reliability. The gathered data was saved initially on MS Excel ${ }^{\circledR}$ file and then later, was imported to IBM SPSS Statistics $23 \circledR$ software. The analysis of this primary data was immediately performed once all the participants completed the questionnaire. Thus, the bulk of the 
statistical analysis was performed using IBM SPSS Statistics $23 \circledR$ software. The total questions of the survey were purposefully divided into two groups. The first group included 48 Likert scale statements and one optional item for the participants to add or share their opinions. The second group included demographic information which included gender, number of years in employment, age and highest academic qualification. All variables were assigned as ordinal (items 1-48) and nominal (items 49-52).

\subsection{The Reliability of the Questionnaire Constructs Using the Cronbach's Alpha Coefficient}

The Cronbach's alpha is considered by several researchers as the most commonly used indicator of internal consistency. It provides reliability estimates from the consistency of item responses from a single assessment. The generally agreed upon lower limit for Cronbach 's alpha is 0.70 (Hair, Anderson, Tatham, \& Black, 1998). Utilizing the IBM SPSS Statistics 23 ${ }^{\circledR}$ package, the consistency reliability of the data was validated by determining the Cronbach's Alpha correlation coefficient. The obtained correlation coefficient obtained was 0.894 and was statistically significant at the 0.01 level as shown in Table 1 .

Table 1. Cronbach's alpha coefficient $(\alpha)$

\begin{tabular}{cc}
\hline \multicolumn{2}{c}{ Reliability Statistics } \\
\hline Cronbach's Alpha & N of Items \\
.894 & 45 \\
\hline
\end{tabular}

The Cronbach's alpha value of the raw data was 0.894 . Thus, the coefficient value for this study exceeded 0.8 , thus satisfying the internal consistency requirements.

\subsection{Demographic Information of the Participants}

The following figures illustrate the demographics of the participants.

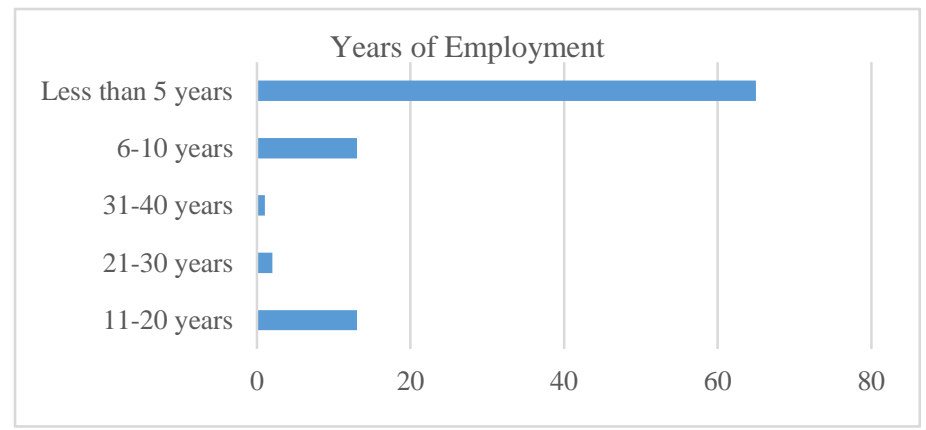

Figure 1. Years of employment of the participants

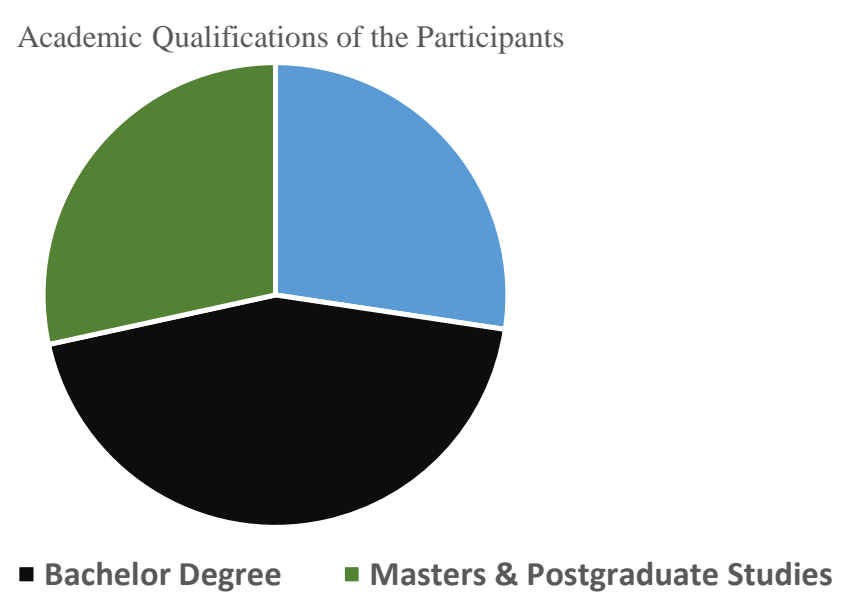

Figure 2. Academic qualifications of the participants 


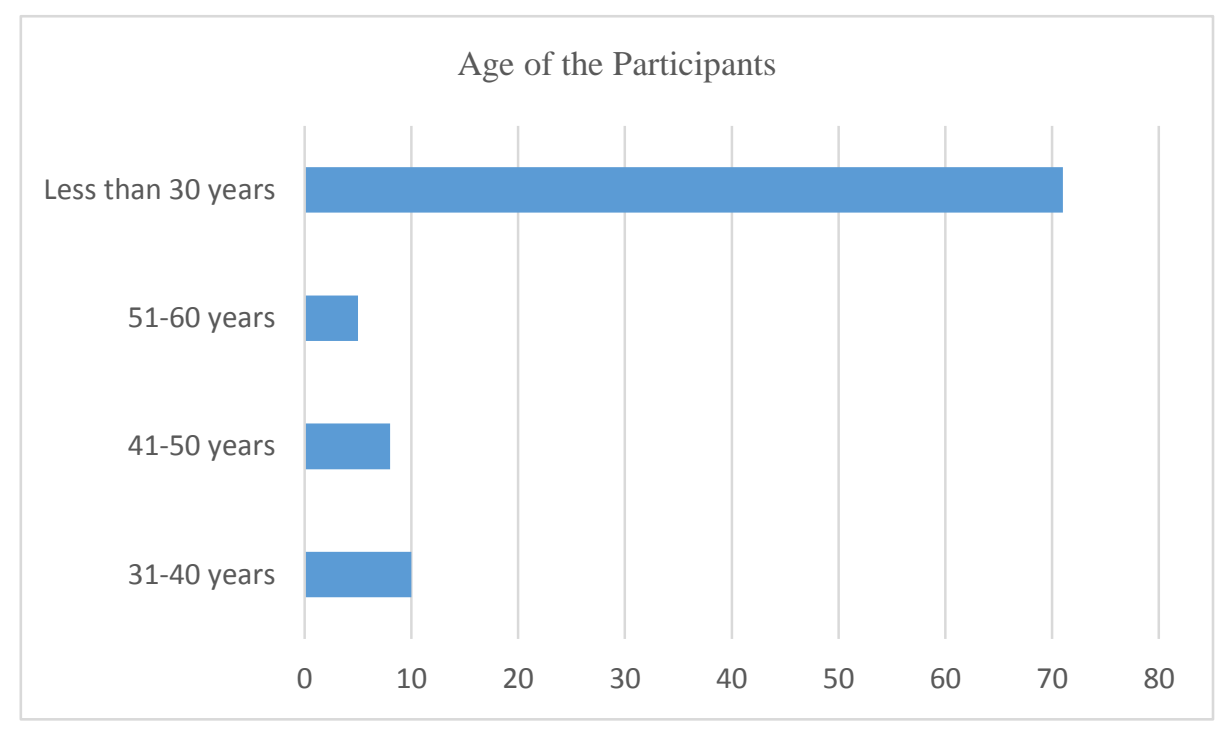

Figure 3. Ages of the participants

The three figures above illustrate that the majority of the participants were less than 30 years of age $(75 \%)$, had less than five years of working experience $(68 \%)$ and had a bachelor degree as their highest academic qualification (44\%). It is worth mentioning here that although the researcher attempted to contact male as well as female potential participants, the responses were only received from male participants.

\subsection{Likert Scale Data Analysis - Research Assumptions}

This research study is informed by ten hypotheses. The statements that each hypothesis is based on are all the Likert item (ordinal nature) data where a representative replacement value is given to each ordinal item so as to allow the data to be analyzed for correlation relationship using Analysis of Variance (one-way ANOVA) as well as independent samples t-test (hypotheses 6 and 9). In order to test the consistency and integrity of the responses as corresponding to the ten hypotheses of this study, a one-way ANOVA as well as independent samples t-test, are used to determine whether there are any significant differences between the means of two (t-test) or more independent (unrelated) groups (Norris, Qureshi, Howitt, \& Cramer, 2014), were used to test for any inconsistencies between the responses of the participants. Thus, statements of predictable assumptions made by the researcher were tested for statistical significant differences so as to formulate a clearer view of responses given by the participants. The results of these analyses are presented below.

Table 2. One-way ANOVA of items 16,19,20,21,23,25,26 and 28

\begin{tabular}{|c|c|c|c|c|c|c|}
\hline \multicolumn{7}{|l|}{ ANOVA } \\
\hline & & $\begin{array}{l}\text { Sum of } \\
\text { Squares }\end{array}$ & df & $\begin{array}{c}\text { Mean } \\
\text { Square }\end{array}$ & $\mathrm{F}$ & Sig. \\
\hline \multirow{3}{*}{$\begin{array}{l}\text { Among the problems associated with foreign laborers is the animosity } \\
\text { foreign labors have towards Saudi citizen and sponsors alike due to the } \\
\text { ill-treatment from both sides, the Saudi citizen and the foreign laborer } \\
\text { who is the actual owner of the small busi }\end{array}$} & \multirow{3}{*}{$\begin{array}{l}\text { Between Groups } \\
\text { Within Groups } \\
\text { Total }\end{array}$} & 2.588 & 2 & 1.294 & 1.121 & .330 \\
\hline & & 106.212 & 92 & 1.154 & & \\
\hline & & 108.800 & 94 & & & \\
\hline \multirow{3}{*}{$\begin{array}{l}\text { Commercial concealment leads to unfair competition and harassment } \\
\text { to Saudi businessmen in the trade industry. }\end{array}$} & Between Groups & 4.052 & 2 & 2.026 & 1.947 & .149 \\
\hline & Within Groups & 95.738 & 92 & 1.041 & & \\
\hline & Total & 99.789 & 94 & & & \\
\hline \multirow{3}{*}{$\begin{array}{l}\text { Some foreign laborers may trade in counterfeit goods and expired } \\
\text { products due to their social backgrounds and poor oversight by the } \\
\text { sponsor and official bodies. }\end{array}$} & Between Groups & 1.063 & 2 & .531 & .928 & .399 \\
\hline & Within Groups & 52.685 & 92 & .573 & & \\
\hline & Total & 53.747 & 94 & & & \\
\hline \multirow{3}{*}{$\begin{array}{l}\text { Problems associated with commercial concealment is the financial } \\
\text { disputes between the Saudi citizen and the foreign laborer practicing } \\
\text { commercial concealment. }\end{array}$} & Between Groups & 2.424 & 2 & 1.212 & 1.580 & .212 \\
\hline & Within Groups & 70.566 & 92 & .767 & & \\
\hline & Total & 72.989 & 94 & & & \\
\hline
\end{tabular}




\begin{tabular}{|c|c|c|c|c|c|c|}
\hline \multirow[t]{3}{*}{ Commercial concealment could lead to tax evasion. } & Between Groups & 1.326 & 2 & .663 & .764 & .469 \\
\hline & Within Groups & 79.895 & 92 & .868 & & \\
\hline & Total & 81.221 & 94 & & & \\
\hline \multirow{3}{*}{$\begin{array}{l}\text { Many foreign businessmen may use some illegal ways in conducting } \\
\text { their businesses which leads to the superiority of the competitive } \\
\text { aspects over the Saudi businessman, such as low quality raw materials } \\
\text { and modest wages. }\end{array}$} & Between Groups & 677 & 2 & .338 & .527 & .592 \\
\hline & Within Groups & 59.113 & 92 & .643 & & \\
\hline & Total & 59.789 & 94 & & & \\
\hline \multirow{3}{*}{$\begin{array}{l}\text { Commercial concealment could lead to exploitation of the Saudi } \\
\text { sponsors by the foreign laborers who may sell the contents of the shop } \\
\text { owned by the sponsor and travel unannounced to their home countries } \\
\text { leaving behind hefty bills for the sponsor to repay s }\end{array}$} & Between Groups & 1.410 & 2 & .705 & .949 & .391 \\
\hline & Within Groups & 68.379 & 92 & .743 & & \\
\hline & Total & 69.789 & 94 & & & \\
\hline \multirow{3}{*}{$\begin{array}{l}\text { Problems associated with commercial concealment is the spread of } \\
\text { fires as a result of the lack of industrial safety due to the ways some } \\
\text { shops are run by foreigners. }\end{array}$} & Between Groups & 2.258 & 2 & 1.129 & .711 & .494 \\
\hline & Within Groups & 146.163 & 92 & 1.589 & & \\
\hline & Total & 148.421 & 94 & & & \\
\hline
\end{tabular}

As the Table 2 above illustrate, the calculated significant $\mathrm{p}$ values were $>0.5$ and thus, the responses of the participants did not differ statistically significantly with regards to the relationship between the widespread of commercial concealment and the performance of small businesses. This indicates that the participants were in agreement with the statements forming the first hypothesis.

Table 3. One-way ANOVA of items 11,13,18,22, and 24

\begin{tabular}{|c|c|c|c|c|c|c|}
\hline \multicolumn{7}{|c|}{ ANOVA } \\
\hline & & $\begin{array}{l}\text { Sum of } \\
\text { Squares }\end{array}$ & df & $\begin{array}{l}\text { Mean } \\
\text { Square }\end{array}$ & $\mathrm{F}$ & Sig. \\
\hline \multirow{3}{*}{$\begin{array}{l}\text { The society's perception of small businesses professions as } \\
\text { culturally inappropriate or low social class work has contributed a } \\
\text { many foreign laborers to fill such a void in these professions and } \\
\text { approach commercial concealment. }\end{array}$} & Between Groups & 1.279 & 2 & .639 & .814 & .446 \\
\hline & Within Groups & 72.258 & 92 & .785 & & \\
\hline & Total & 73.537 & 94 & & & \\
\hline \multirow{3}{*}{$\begin{array}{l}\text { Due to the deep-rootedness of commercial concealment among } \\
\text { foreign laborers in KSA, it has led to the presence of commercial } \\
\text { gatherings which controls certain types of trades such as garages } \\
\text { and readymade garments, building materials and restaurants. }\end{array}$} & Between Groups & 2.808 & 2 & 1.404 & 2.635 & .077 \\
\hline & Within Groups & 49.023 & 92 & .533 & & \\
\hline & Total & 51.832 & 94 & & & \\
\hline \multirow{3}{*}{$\begin{array}{l}\text { Many of the commercial and service providing businesses such as } \\
\text { engineering and information technology, are controlled by foreign } \\
\text { laborers and might be an actual commercial concealment. }\end{array}$} & Between Groups & .503 & 2 & .251 & .244 & .784 \\
\hline & Within Groups & 94.802 & 92 & 1.030 & & \\
\hline & Total & 95.305 & 94 & & & \\
\hline \multirow{3}{*}{$\begin{array}{l}\text { Commercial concealment prevents many of those who wish to start } \\
\text { their small businesses. }\end{array}$} & Between Groups & .806 & 2 & .403 & .470 & .627 \\
\hline & Within Groups & 78.941 & 92 & .858 & & \\
\hline & Total & 79.747 & 94 & & & \\
\hline \multirow{3}{*}{$\begin{array}{l}\text { Commercial concealment has led to the presence of large numbers } \\
\text { of foreigners who pay large amount of money to enter the field of } \\
\text { Commercial concealment due to the substantial profits it generates. }\end{array}$} & Between Groups & .769 & 2 & .385 & .717 & .491 \\
\hline & Within Groups & 49.336 & 92 & .536 & & \\
\hline & Total & 50.105 & 94 & & & \\
\hline
\end{tabular}

From Table 3 above, it can be seen that the calculated significant $p$ values were also $>0.5$ and thus, the responses of the participants did not differ statistically significantly with regards to the widespread of commercial concealment and the inability of many Saudi citizens in starting up small businesses. This indicates that the participants were in agreement with the statements forming the first hypothesis. 
Table 4. One-way ANOVA of items 1,2,4,8,9, and 10

\begin{tabular}{|c|c|c|c|c|c|c|}
\hline \multicolumn{7}{|c|}{ ANOVA } \\
\hline & & Sum of Squares & df & Mean Square & $\mathrm{F}$ & Sig. \\
\hline \multirow{3}{*}{$\begin{array}{l}\text { One the reasons for the spread of commercial } \\
\text { concealment is the lack of strict laws that is able to } \\
\text { eliminate this phenomenon. }\end{array}$} & Between Groups & 7.153 & 2 & 3.577 & 4.011 & .021 \\
\hline & Within Groups & 82.047 & 92 & .892 & & \\
\hline & Total & 89.200 & 94 & & & \\
\hline \multirow{3}{*}{$\begin{array}{l}\text { The lack of routine checkups and strict inspections in the } \\
\text { commercial markets has led to the spread of the } \\
\text { commercial concealment phenomenon }\end{array}$} & Between Groups & .362 & 2 & .181 & .504 & .606 \\
\hline & Within Groups & 33.069 & 92 & .359 & & \\
\hline & Total & 33.432 & 94 & & & \\
\hline \multirow{3}{*}{$\begin{array}{l}\text { One of the reasons for commercial concealment is the } \\
\text { illegal trading in work visas by some citizens. }\end{array}$} & Between Groups & .743 & 2 & .372 & .877 & .420 \\
\hline & Within Groups & 39.004 & 92 & .424 & & \\
\hline & Total & 39.747 & 94 & & & \\
\hline \multirow{3}{*}{$\begin{array}{l}\text { One of the main reasons for the spread of commercial } \\
\text { concealment is the ease with which foreign workers can } \\
\text { escape from their sponsor or place of work. }\end{array}$} & Between Groups & 9.632 & 2 & 4.816 & 4.734 & .011 \\
\hline & Within Groups & 93.589 & 92 & 1.017 & & \\
\hline & Total & 103.221 & 94 & & & \\
\hline \multirow{3}{*}{$\begin{array}{l}\text { A large number of small businesses are in fact projects } \\
\text { owned by foreign businessmen. }\end{array}$} & Between Groups & 1.368 & 2 & .684 & .665 & .517 \\
\hline & Within Groups & 94.569 & 92 & 1.028 & & \\
\hline & Total & 95.937 & 94 & & & \\
\hline \multirow{3}{*}{$\begin{array}{l}\text { Many of the franchise companies that fall under the guise } \\
\text { of commercial concealment has a very high ratio of } \\
\text { foreign staff. }\end{array}$} & Between Groups & .519 & 2 & .259 & .344 & .710 \\
\hline & Within Groups & 69.313 & 92 & .753 & & \\
\hline & Total & 69.832 & 94 & & & \\
\hline
\end{tabular}

Similarly, from table 4 above, it can be seen that the calculated significant $\mathrm{p}$ values were all $>0.05$ (barring item 1 and 10) indicating no statistically significant differences in the responses of the participants except items 1 and 10. This might be due to the fact that the participants may hold different views on whether the state has strict laws in combating commercial concealment (they obviously different in their opinions) and whether or not it is easy for foreign worker to run away from their employer. However, it seems that the majority of the participants have a consensus on the items forming the third hypothesis.

Table 5. One-way ANOVA of items 12,15,43 and 45

\begin{tabular}{|c|c|c|c|c|c|c|}
\hline \multicolumn{7}{|c|}{ ANOVA } \\
\hline & & $\begin{array}{l}\text { Sum of } \\
\text { Squares }\end{array}$ & df & $\begin{array}{l}\text { Mean } \\
\text { Square }\end{array}$ & $\mathrm{F}$ & Sig. \\
\hline \multirow{3}{*}{$\begin{array}{l}\text { One of the reasons for the spread of commercial concealment is the } \\
\text { aiding of some Saudi citizens to a foreigner to work in the field of } \\
\text { commercial concealment in exchange for a low monthly payments } \\
\text { of foreign businessmen to the Saudi citizen. }\end{array}$} & Between Groups & 2.083 & 2 & 1.041 & 1.345 & .266 \\
\hline & Within Groups & 71.223 & 92 & .774 & & \\
\hline & Total & 73.305 & 94 & & & \\
\hline \multirow{3}{*}{$\begin{array}{l}\text { Tolerance and naivety of some members of Saudi society has led to } \\
\text { foreign exploitation of the Saudi citizen to work under the guise of } \\
\text { commercial concealment. }\end{array}$} & Between Groups & .227 & 2 & .114 & .089 & .914 \\
\hline & Within Groups & 115.486 & 91 & 1.269 & & \\
\hline & Total & 115.713 & 93 & & & \\
\hline \multirow{3}{*}{$\begin{array}{l}\text { The need to spread cultural awareness among Saudi citizens on the } \\
\text { dangers of commercial concealment and issue fines on those who } \\
\text { trade and work in commercial concealment. }\end{array}$} & Between Groups & .492 & 2 & .246 & .560 & .573 \\
\hline & Within Groups & 39.934 & 91 & .439 & & \\
\hline & Total & 40.426 & 93 & & & \\
\hline \multirow{3}{*}{$\begin{array}{l}\text { The need for the foreign laborer changing sponsors in Saudi Arabia } \\
\text { to have a no objection and release letter from the last sponsor. }\end{array}$} & Between Groups & .121 & 2 & .060 & .062 & .940 \\
\hline & Within Groups & 89.500 & 92 & .973 & & \\
\hline & Total & 89.621 & 94 & & & \\
\hline
\end{tabular}

From Table 5 above, it can be seen that the calculated significant $\mathrm{p}$ values were all $>0.5$ and thus, the responses of the participants did not differ statistically significantly with regards to the relationship between the citizens' awareness and the spread of commercial concealment. This indicates that the participants were in agreement with the statements forming the fourth hypothesis. 
Table 6. One-way ANOVA of items 6,7,14 and 30

\begin{tabular}{|c|c|c|c|c|c|c|}
\hline \multicolumn{7}{|c|}{ ANOVA } \\
\hline & & Sum of Squares & df & Mean Square & $\mathrm{F}$ & Sig. \\
\hline \multirow{3}{*}{$\begin{array}{l}\text { The lack of job opportunities in the countries of the } \\
\text { foreign workers and extreme rarity in some countries, has } \\
\text { contributed to the influx of foreigners working in the field } \\
\text { of commercial concealment. }\end{array}$} & Between Groups & 2.428 & 2 & 1.214 & 1.208 & .304 \\
\hline & Within Groups & 92.477 & 92 & 1.005 & & \\
\hline & Total & 94.905 & 94 & & & \\
\hline \multirow{3}{*}{$\begin{array}{l}\text { Large profits gained from hand craft businesses led to an } \\
\text { increase in foreigners who enter the field of commercial } \\
\text { concealment as one the main reasons for their arrival to } \\
\text { conduct such a business in the Kingdom of Saudi Arabia. }\end{array}$} & Between Groups & 2.012 & 2 & 1.006 & 1.512 & .226 \\
\hline & Within Groups & 61.209 & 92 & .665 & & \\
\hline & Total & 63.221 & 94 & & & \\
\hline \multirow{3}{*}{$\begin{array}{l}\text { Non-Stop work in commercial concealment businesses run } \\
\text { by foreign laborers alternately, meant that their workplace } \\
\text { is also their place of accommodation and residence. }\end{array}$} & Between Groups & 2.070 & 2 & 1.035 & 1.022 & .364 \\
\hline & Within Groups & 93.130 & 92 & 1.012 & & \\
\hline & Total & 95.200 & 94 & & & \\
\hline \multirow{3}{*}{$\begin{array}{l}\text { Businesses and that are just a cover and are owned by } \\
\text { foreign businessmen are connected to money laundering. }\end{array}$} & Between Groups & .881 & 2 & .440 & .479 & .621 \\
\hline & Within Groups & 84.656 & 92 & .920 & & \\
\hline & Total & 85.537 & 94 & & & \\
\hline
\end{tabular}

Table 6 above indicates that the calculated significant $\mathrm{p}$ values were all $>0.5$ and thus, the responses of the participants did not differ statistically significantly with regards to the items $6,7,14$ and 30 forming the fifth hypothesis which is related to the relationship between the economical problems and the spread of commercial concealment. This indicates that the participants were in agreement with the statements forming the fifth hypothesis.

Table 7. Independent sample t-test of 17 and 29

\begin{tabular}{|c|c|c|c|c|}
\hline \multicolumn{5}{|c|}{ Group Statistics } \\
\hline Item & $\mathrm{N}$ & Mean & Std. Deviation & Std. Error Mean \\
\hline $\begin{array}{l}\text { Problems associated with commercial concealment is the spread of the } \\
\text { phenomenon of bribery and corruption among the Saudi and foreign } \\
\text { citizens as well as some official agencies staff. }\end{array}$ & 95 & 1.94 & .965 & .099 \\
\hline $\begin{array}{l}\text { The presence of large numbers of foreign businessmen who are residing } \\
\text { without their wives led to the spread of prostitution in the society and the } \\
\text { emergence of bad social habits. }\end{array}$ & 95 & 2.15 & 1.072 & .110 \\
\hline
\end{tabular}

In Table 7 above, the two groups of responses of the participants to items 17 and 29 are computed for statistical significant differences and since the calculated two $\mathrm{p}$ values were $>0.05$, we can see that there is no statistically significant difference between the responses of the respondents to these two items and thus, confirm the sixth hypothesis of correlation between social problems and commercial concealment.

Table 8. One-way ANOVA of items 31,32,33,34,35,36,37,38 and 42

\begin{tabular}{|c|c|c|c|c|c|c|}
\hline \multicolumn{7}{|c|}{ ANOVA } \\
\hline & & Sum of Squares & df & Mean Square & $\mathrm{F}$ & Sig. \\
\hline \multirow{3}{*}{$\begin{array}{l}\text { Saudization of the private sector and small enterprises } \\
\text { helps in reducing the phenomenon of commercial } \\
\text { concealment. }\end{array}$} & Between Groups & 3.221 & 2 & 1.611 & 2.043 & .135 \\
\hline & Within Groups & 72.526 & 92 & .788 & & \\
\hline & Total & 75.747 & 94 & & & \\
\hline \multirow{3}{*}{$\begin{array}{l}\text { It should not be allowed for the Saudi sponsor to } \\
\text { transfer the work visa of the foreign laborer working in } \\
\text { small projects or small businesses. }\end{array}$} & Between Groups & 2.144 & 2 & 1.072 & 1.110 & .334 \\
\hline & Within Groups & 88.845 & 92 & .966 & & \\
\hline & Total & 90.989 & 94 & & & \\
\hline \multirow{3}{*}{$\begin{array}{l}\text { It should not be allowed for the foreign laborers and } \\
\text { migrant workers in the private and small projects to } \\
\text { work for more than three years and their work visas } \\
\text { should not be renewed in any way or form after that. }\end{array}$} & Between Groups & .903 & 2 & .452 & .330 & .720 \\
\hline & Within Groups & 126.044 & 92 & 1.370 & & \\
\hline & Total & 126.947 & 94 & & & \\
\hline
\end{tabular}




\begin{tabular}{|c|c|c|c|c|c|c|}
\hline \multirow{3}{*}{$\begin{array}{l}\text { The use of iris scans at border controls and airports will } \\
\text { limit the return of foreign laborers visa violators. }\end{array}$} & Between Groups & 1.722 & 2 & .861 & \multirow[t]{3}{*}{1.975} & \multirow[t]{3}{*}{.145} \\
\hline & Within Groups & 40.109 & 92 & .436 & & \\
\hline & Total & 41.832 & 94 & & & \\
\hline \multirow{3}{*}{$\begin{array}{l}\text { Tightening controls on counterfeit and expired products } \\
\text { will help in identifying its sources. }\end{array}$} & Between Groups & .155 & 2 & .077 & \multirow[t]{3}{*}{.225} & \multirow[t]{3}{*}{.799} \\
\hline & Within Groups & 31.635 & 92 & .344 & & \\
\hline & Total & 31.789 & 94 & & & \\
\hline \multirow{3}{*}{$\begin{array}{l}\text { Any illegal actions carried out by the foreign laborers } \\
\text { should be punished by deportation and not allowing } \\
\text { them to return to work in the Kingdom again. }\end{array}$} & Between Groups & 1.804 & 2 & .902 & \multirow[t]{3}{*}{1.907} & \multirow[t]{3}{*}{.154} \\
\hline & Within Groups & 43.501 & 92 & .473 & & \\
\hline & Total & 45.305 & 94 & & & \\
\hline \multirow{3}{*}{$\begin{array}{l}\text { Issuing e-cards for each foreign laborer will help in } \\
\text { identifying his place of work and residence and also, } \\
\text { helps in identifying his income and transactions. }\end{array}$} & Between Groups & .053 & 2 & .027 & \multirow[t]{3}{*}{.083} & \multirow[t]{3}{*}{.920} \\
\hline & Within Groups & 29.378 & 92 & .319 & & \\
\hline & Total & 29.432 & 94 & & & \\
\hline \multirow{3}{*}{$\begin{array}{l}\text { Due to the fact that some foreign laborers belonging to } \\
\text { specific nationalities who are involved in commercial } \\
\text { concealment such Indians, Bengalis and the Syrians, it } \\
\text { is recommended that they are not recruited to the } \\
\text { Kingdom to work in the private sector. }\end{array}$} & Between Groups & 1.336 & 2 & .668 & \multirow[t]{3}{*}{.438} & \multirow[t]{3}{*}{.647} \\
\hline & Within Groups & 140.453 & 92 & 1.527 & & \\
\hline & Total & 141.789 & 94 & & & \\
\hline \multirow{3}{*}{$\begin{array}{l}\text { Not to allow the transfer of funds in cash through } \\
\text { customs, ports and confiscate all such ceased money by } \\
\text { the state and prevent guilty foreign workers from } \\
\text { entering the country again. }\end{array}$} & Between Groups & 1.021 & 2 & .511 & \multirow[t]{3}{*}{.563} & \multirow[t]{3}{*}{.572} \\
\hline & Within Groups & 83.463 & 92 & .907 & & \\
\hline & Total & 84.484 & 94 & & & \\
\hline
\end{tabular}

As can be seen from Table 8 above, the calculated $p$ values were all $>0.05$ and thus, indicates no statistically significant difference in the responses of the participants to the 9 items forming the seventh hypothesis which indicates the correlation between government bodies' roles in combating commercial concealment.

Table 9. One-way ANOVA of items 3,39,40 and 41

\begin{tabular}{|c|c|c|c|c|c|c|}
\hline \multicolumn{7}{|c|}{ ANOVA } \\
\hline & & Sum of Squares & df & Mean Square & $\mathrm{F}$ & Sig. \\
\hline \multirow{3}{*}{$\begin{array}{l}\text { One of the main reasons for the occurrence of } \\
\text { commercial concealment is the lack of specialized } \\
\text { government agencies in the commercial banks to } \\
\text { monitor commercial concealment transactions. }\end{array}$} & Between Groups & 3.204 & 2 & 1.602 & 2.144 & .123 \\
\hline & Within Groups & 68.754 & 92 & .747 & & \\
\hline & Total & 71.958 & 94 & & & \\
\hline \multirow{3}{*}{$\begin{array}{l}\text { There should be some type of cooperation with } \\
\text { commercial centers to investigate foreign laborers } \\
\text { who work in these centers who might be actually } \\
\text { working under the guise commercial concealment. }\end{array}$} & Between Groups & .206 & 2 & .103 & .321 & .726 \\
\hline & Within Groups & 29.541 & 92 & .321 & & \\
\hline & Total & 29.747 & 94 & & & \\
\hline \multirow{3}{*}{$\begin{array}{l}\text { Salaries paid to foreign laborers working in small } \\
\text { enterprises must be paid directly to a bank account } \\
\text { rather than in cash. }\end{array}$} & Between Groups & 1.134 & 2 & .567 & .727 & .486 \\
\hline & Within Groups & 71.771 & 92 & .780 & & \\
\hline & Total & 72.905 & 94 & & & \\
\hline \multirow{2}{*}{$\begin{array}{l}\text { It is important that bank accounts of foreign laborers } \\
\text { as well as the Saudi owners of commercial licenses } \\
\text { are monitored so as to keep track of any } \\
\text { discrepancies between the official income of the } \\
\text { foreign laborer and that of the Saudi owner at the end } \\
\text { of e }\end{array}$} & Between Groups & 2.039 & 2 & 1.019 & 1.181 & .312 \\
\hline & $\begin{array}{l}\text { Within Groups } \\
\text { Total }\end{array}$ & 79.393 & 92 & .863 & & \\
\hline
\end{tabular}

Similarly, Table 9 above indicate that the responses of the participants to the four items forming the eights hypothesis did not statistically significantly differ and that is evident from the calculated $\mathrm{p}$ values which were all $>0.05$ indicating no statistical significant difference between them and thus accepting the correlation between the role of the private sector (including commercial banks) and their impact in combating commercial concealment. 
Table 10. One-way ANOVA of sub-items of 27 and 47

\begin{tabular}{|c|c|c|c|c|c|c|}
\hline \multicolumn{7}{|c|}{ ANOVA } \\
\hline & & Sum of Squares & df & Mean Square & $\mathrm{F}$ & Sig. \\
\hline \multirow{3}{*}{$\begin{array}{l}\text { Nationalities of foreign laborers working in } \\
\text { commercial concealment (listed as reflecting } \\
\text { specialty) }\end{array}$} & Between Groups & 7.164 & 2 & 3.582 & 1.064 & .349 \\
\hline & Within Groups & 309.741 & 92 & 3.367 & & \\
\hline & Total & 316.905 & 94 & & & \\
\hline \multirow{3}{*}{$\begin{array}{l}\text { Nationalities of foreign laborers working in } \\
\text { commercial concealment (listed as reflecting } \\
\text { specialty) }\end{array}$} & Between Groups & 4.840 & 2 & 2.420 & .275 & .760 \\
\hline & Within Groups & 809.118 & 92 & 8.795 & & \\
\hline & Total & 813.958 & 94 & & & \\
\hline \multirow{3}{*}{$\begin{array}{l}\text { Nationalities of foreign laborers working in } \\
\text { commercial concealment (listed as reflecting } \\
\text { specialty) }\end{array}$} & Between Groups & 1.743 & 2 & .871 & .189 & .828 \\
\hline & Within Groups & 423.247 & 92 & 4.601 & & \\
\hline & Total & 424.989 & 94 & & & \\
\hline \multirow{3}{*}{$\begin{array}{l}\text { Nationalities of foreign laborers working in } \\
\text { commercial concealment (listed as reflecting } \\
\text { specialty) }\end{array}$} & Between Groups & 32.623 & 2 & 16.312 & .506 & .604 \\
\hline & Within Groups & 2962.913 & 92 & 32.206 & & \\
\hline & Total & 2995.537 & 94 & & & \\
\hline \multirow{3}{*}{$\begin{array}{l}\text { Nationalities of foreign laborers working in } \\
\text { commercial concealment (listed as reflecting } \\
\text { specialty) }\end{array}$} & Between Groups & 44.936 & 2 & 22.468 & 1.069 & .348 \\
\hline & Within Groups & 1933.801 & 92 & 21.020 & & \\
\hline & Total & 1978.737 & 94 & & & \\
\hline \multirow{3}{*}{$\begin{array}{l}\text { Nationalities of foreign laborers working in } \\
\text { commercial concealment (listed as reflecting } \\
\text { specialty) }\end{array}$} & Between Groups & 7.500 & 2 & 3.750 & .295 & .746 \\
\hline & Within Groups & 1171.384 & 92 & 12.732 & & \\
\hline & Total & 1178.884 & 94 & & & \\
\hline \multirow{3}{*}{$\begin{array}{l}\text { Please rank the following nationalities starting } \\
\text { with that that deals the most commercial } \\
\text { concealment }\end{array}$} & Between Groups & 18.177 & 2 & 9.089 & 1.637 & .200 \\
\hline & Within Groups & 510.728 & 92 & 5.551 & & \\
\hline & Total & 528.905 & 94 & & & \\
\hline \multirow{3}{*}{$\begin{array}{l}\text { Please rank the following nationalities starting } \\
\text { with that that deals the most commercial } \\
\text { concealment }\end{array}$} & Between Groups & 1.469 & 2 & .735 & .117 & .890 \\
\hline & Within Groups & 579.731 & 92 & 6.301 & & \\
\hline & Total & 581.200 & 94 & & & \\
\hline \multirow{3}{*}{$\begin{array}{l}\text { Please rank the following nationalities starting } \\
\text { with that that deals the most commercial } \\
\text { concealment }\end{array}$} & Between Groups & 2.773 & 2 & 1.387 & .209 & .812 \\
\hline & Within Groups & 610.763 & 92 & 6.639 & & \\
\hline & Total & 613.537 & 94 & & & \\
\hline \multirow{3}{*}{$\begin{array}{l}\text { Please rank the following nationalities starting } \\
\text { with that that deals the most commercial } \\
\text { concealment }\end{array}$} & Between Groups & 9.370 & 2 & 4.685 & .881 & .418 \\
\hline & Within Groups & 489.514 & 92 & 5.321 & & \\
\hline & Total & 498.884 & 94 & & & \\
\hline \multirow{3}{*}{$\begin{array}{l}\text { Please rank the following nationalities starting } \\
\text { with that that deals the most commercial } \\
\text { concealment }\end{array}$} & Between Groups & 9.908 & 2 & 4.954 & .635 & .532 \\
\hline & Within Groups & 717.313 & 92 & 7.797 & & \\
\hline & Total & 727.221 & 94 & & & \\
\hline \multirow{3}{*}{$\begin{array}{l}\text { Please rank the following nationalities starting } \\
\text { with that that deals the most commercial } \\
\text { concealment }\end{array}$} & Between Groups & 12.397 & 2 & 6.198 & .788 & .458 \\
\hline & Within Groups & 723.961 & 92 & 7.869 & & \\
\hline & Total & 736.358 & 94 & & & \\
\hline \multirow{3}{*}{$\begin{array}{l}\text { Please rank the following nationalities starting } \\
\text { with that that deals the most commercial } \\
\text { concealment }\end{array}$} & Between Groups & .182 & 2 & .091 & .020 & .980 \\
\hline & Within Groups & 419.966 & 92 & 4.565 & & \\
\hline & Total & 420.147 & 94 & & & \\
\hline \multirow{3}{*}{$\begin{array}{l}\text { Please rank the following nationalities starting } \\
\text { with that that deals the most commercial } \\
\text { concealment }\end{array}$} & Between Groups & 17.980 & 2 & 8.990 & 1.541 & .220 \\
\hline & Within Groups & 536.610 & 92 & 5.833 & & \\
\hline & Total & 554.589 & 94 & & & \\
\hline
\end{tabular}

Table 9 above illustrates the consensus among the participants in their perception of the relationship between the various crafts and jobs and the nationalities that control these jobs that are involved in commercial concealment. It is evident from the calculated $p$ values $(>0.05)$ that the participants were mainly in agreement and thus, an indication of the relationship stated in the ninth hypothesis. 
Table 11. One-way ANOVA of sub-items 5, 44 and 46

\begin{tabular}{|c|c|c|c|c|c|c|}
\hline \multicolumn{7}{|l|}{ ANOVA } \\
\hline & & $\begin{array}{l}\text { Sum of } \\
\text { Squares }\end{array}$ & df & $\begin{array}{c}\text { Mean } \\
\text { Square }\end{array}$ & $\mathrm{F}$ & Sig. \\
\hline \multirow{3}{*}{$\begin{array}{l}\text { One of the reasons for the spread of commercial concealment is the } \\
\text { need to employ foreign laborers in certain professions which has } \\
\text { contributed to the spread of this phenomenon. }\end{array}$} & Between Groups & .434 & 2 & .217 & .185 & .831 \\
\hline & Within Groups & 107.924 & 92 & 1.173 & & \\
\hline & Total & 108.358 & 94 & & & \\
\hline \multirow{3}{*}{$\begin{array}{l}\text { Commercial concealment is sometimes a necessary evil, especially in } \\
\text { the medical profession where medical services and treatment is } \\
\text { important to the community since the Saudi citizens are unable to } \\
\text { provide because of the lack of this experience. }\end{array}$} & Between Groups & 6.794 & 2 & 3.397 & 1.626 & .202 \\
\hline & Within Groups & 192.196 & 92 & 2.089 & & \\
\hline & Total & 198.989 & 94 & & & \\
\hline \multirow{3}{*}{$\begin{array}{l}\text { It is important not to deal with commercial concealment in one go, } \\
\text { but rather on separate stages so as to prevent paralysis of health } \\
\text { services and restaurants. }\end{array}$} & Between Groups & 3.022 & 2 & 1.511 & 1.032 & .360 \\
\hline & Within Groups & 134.662 & 92 & 1.464 & & \\
\hline & Total & 137.684 & 94 & & & \\
\hline
\end{tabular}

The last hypothesis in this research study, the tenth hypothesis, is informed by items 5,44 and 46 . It is evident from Table 11 above that the participants were in agreement on their responses to these items which is clear from the calculated $\mathrm{p}$ values which were all $>0.05$ and thus indicating that there are some benefits to having commercial concealment (to an extent) in that it keeps the economic cycle going and makes the contributions to certain venues such as building, trade and services.

\section{Recommendations}

The main causes for the spread of commercial concealment are identified on three levels; namely, the citizen, official bodies and the foreigner.

\subsection{First: On the Citizen's Level}

Endeavor to provide the necessary procedures that aim at Saudization of jobs in order to completely prevent the presence of foreigners in Saudi shops. This action shall clear the heavy concentration of foreigners in markets, especially in the ready-made garments trade, car workshops, electronics maintenance workshops, restaurants, means of transportation, the contracting sector and dental clinics (Fakeeh, 2009). The Saudization of jobs has an important role in combating unemployment among Saudis (Al-Dosary \& Rahman, 2005).

Idleness of the citizen and non-engagement in private businesses which require continuous work, perseverance, prior experience and a risk-taking attitude.

Lack of citizens' awareness and avoidance of tolerance and kindness.

The need to identify the reasons which lead the citizen to conceal the foreigner's activities (financial incentives, lack of punishment, or non-imposition of law and systems).

To impose punishment upon Saudis who financially benefit from trading in visas.

Develop effective legal and punishment systems to deter citizens who do not abide by or comply with the laws, rules and regulations.

\subsection{Second: On the Official Bodies' Level}

- Reduce the retirement age to give some employees the chance to start their private businesses. This will provide jobs for young people and give mothers the opportunity to care for their families (Ramzi, 2013).

- Inspection field tours (Al-Amari, 2015).

- Monitoring of cash transactions.

- Terminate the sponsorship (Kafala) system or update it (Al-Ghamdi, 2012).

- Set incentive awards for investigators, businessmen, local workers' unions and scientific research centers which contribute in solving the problems raised by commercial concealment.

- Benefit from the previous experience of other countries in this matter.

\subsection{Third: On the Foreign Workers' Level}

- Prevent the transfer of the entire revenues of foreigners and maintain a portion to be invested in investment tools such as stock, particularly for franchise companies, and pay closer attention to tax payments. 
- Compel the worker to work in the sponsor's corporation to eliminate commercial concealment practices and dummy corporations. In case a worker escapes from his sponsor, a financial penalty shall be imposed, in addition to deportation and prevention of the worker to return to work again in the Kingdom.

- Prevent visas for Syrians, Bangladeshis, Indians, Pakistanis and replace them with other nationalities such as Filipinos and Indonesians.

- Control fake certificates which contribute to the spread of this phenomenon, especially among doctors and engineers.

- Cooperate with embassies to restrict the issuance of replacement passports (Al-Ghamdi, 2012).

- The criminalization of workers who run away from their sponsors is a better solution than deportation (Al-Hinady, 2012).

- Prevent the accommodation of foreign labor at popular houses and homes.

- Prevent the accommodation of foreign labor at their work premises.

- Surveillance of workers throughout their working hours not exceeding 8 hours.

- Prevent the elderly non-skilled workers from work so as not to initiate their private businesses - since many of them have previous experience in private business.

- Limit the issuance of visas to certain conditions. For example, issuance shall be restricted to a specific number, if exceeded, the visa shall be rejected altogether.

- Prevent visa renewal for more than four years.

- Set up outdoor surveillance cameras in markets to monitor the movements of labor especially during field inspection tours.

- Monitor the movements of questionable and doubtful labor.

\section{References}

Al-Abdulali, A. (2003). The Role of the Ministry of Commerce in Combating Commercial Concealment. A Lecture Presented at the Chamber of Commerce in Riyadh, Saudi Arabia.

Al-Amri, A. (2015). The Elimination of Commercial Concealment. Al-Arabiyya Satellite Channel. International Commercial Program, January 21, 2015, Saudi Arabia.

Al-Balwai, A. (2016). Rise in Unemployment, Increase in the Number of Foreign Laborers, Increase in Runaway Foreign Laborers and Cost of Employing Foreign Laborers. Manifests Awaiting Decisiveness. Al-Riyadh Newspaper, No. 17382, 26th of January, 2016. Saudi Arabia.

Al-Bawardi, R. et al. (2013). The Commercial Concealment Prevention Law Project is No Longer Applicable. Al-Ru'iah Newspaper, No. 268. 27th of August, 2013. UAE.

Al-Dani, A. et al. (2013). The Corrective Campaign Will Eliminate 50\% of Commercial Concealment Problems. Okath Saudi Daily Newspaper, 2nd of November, 2013.

Al-Dosary, A., \& Rahman, S. (2005). Saudization (Localization): A Critical Review. Human Resource Development International, 8(4). http://dx.doi.org/10.1080/13678860500289534

Al-Ghamdi, M. (2012). The Abolition of the "Sponsorship System" Eliminates the Commercial Concealment and the "Visa Trade" and "Phantom Establishments"! Al-Riyadh Newspaper, No. 16185, 16th of October, 2012. Saudi Arabia.

Al-Ghamri, N. (2009). The Management of Small Businesses and Indicators of their Success (4th ed.). Jeddah, Saudi Arabia: Dar Hafez Publications.

Al-Hinady, A. (2012). The Run Away of Workers Delays Contractors' Project. Al-Riyadh Daily Newspaper, No. 16105, 28th of July, 2012.

Al-Ka'abi, J. (2014). The Commercial Concealment Prevention Law "In Its Core". Al-Watan Newspaper, No. 6822, 5th of August, 2014. Saudi Arabia.

Al-Khamisi, K. (2013). Legal Settlement of Immigration Status of Foreign Laborers Minimizes Shadow Economy in Saudi Arabia. Al-Iqtisadiyyah Newspaper, No. 7174, 2nd of June, 2013. Saudi Arabia.

Al-Mansour, A. (2003). An Expert: "Commercial Concealment in Saudi Arabia is Draining the National Economy, Reduces Savings and Allows for Price Manipulations. Al-Sharq Al-Awsat Newspaper, No. 8988, 
8th of July, 2003. Saudi Arabia.

Al-Naqmy, A. (2013). The Flight of Saudi Young People from Work and Their Slacking in Doing Their Jobs Properly. Al-Madinah Saudi Daily Newspaper, 5th of April, 2013.

Al-Omari, F. (2015). Ministry of Labor Bans the Employment of Men's Laborers in Ladies Tailoring Shops. OKAZ Newspaper, 15th of October 2015, Saudi Arabia.

Al-Ruwais, K. (2014). Commercial Concealment and Sponsorship. Labor Policies and Sustainable Development Conference. The Omani Economic Society in Collaboration with King Saud University. Muscat - Oman. 9th - 10th March, 2014.

Al-Salem, S. (2011). A Legal Expert: "Commercial Concealment is Like Cancer Threatening Our Economy. Al-Riyadh Newspaper, No. 15626, 6th of April, 2011, Saudi Arabia.

Al-Shaiban, I. (2015). 50\% of Commercial Concealment is in Transportation Sector in Eastern Province While Only Six Government Monitors are in charge of Ten Thousand Facilities! Al-Riyadh Saudi Newspaper, Issue No. 17121, May 10th, 2015, Saudi Arabia.

Al-Shamasy, M. (2006). Evaluation of Labour Immigration Policies in the GCC: Lessons for the Future. Department of Economic and Social Affairs, United Nations Secretariat, Beirut, 15-17 May 2006.

Al-Sharif, M. (2016). 80\% of Commercial Concealment is in the Mobile Phones Sector. The Saudi Businessman is the Hardest Hit and Foreign Laborers Control the Market. Al-Madinah Saudi Newspaper, Issue No. 19331, 25th of March 2016.

Al-Shayaa, K. (2010). Medical Errors Cause 2500 Deaths Annually in Saudi Arabia and The Public Demand Stricter Medical Observation and Supervision. Arabic Satellite Channel Online, 24th of March, 2010.

Al-Suhaimi, A. (2011). Commercial Concealment, its Harms and Consequences. Master Dissertation, Taibah University, Saudi Arabia.

Al-Turki, B. (2015). Commercial Concealment in Building Construction, an Obstacle Facing Seekers of Genuine Business Opportunities. Al-Watan Online Saudi Newspaper, 22nd of November, 2015.

Al-Zahrani, S. (2012). Today's Saudi Youths Will Not Compete with Five Million Foreign Laborers' Low Salaries Without an Increase in the Cost of Labor. Okath Newspaper, Issue No. 4213, 29th of December, 2012, Saudi Arabia.

Anand, G. (2013). Report of the Special Rapporteur on the Right of Everyone to the Enjoyment of the Highest Attainable Standards of Physical and Mental Health. General Assembly, the United Nations on Human Rights Council, 23rd Session, Item (3) of the Agenda: The Promotion and Protection of All Human Rights, Civil, Political, Economic, Social and Cultural Rights, Including the Right to Development. 15th of May, 2013.

Asiri, M. (2015). Experts: Foreign Labour Lead "Small Businesses" Destruction with Commercial Concealment. Al-Madinah Saudi Newspaper, Issue No. 19335, 6th of October, 2015, Saudi Arabia.

Assaf, S., Srour, O., \& Hassanain, M. (2013). Causes of Failure of Small Contractors in Saudi Arabia. International Journal of Construction Management, 2013. http://dx.doi.org/10.1080/15623599.2013.10878226

Atwi, A., \& Al-Bawardi, R. (2013). Commercial Concealment Project Law Is No Longer Applicable. AlRu'ayah Newspaper, Issue No 268, 27th of August, 2013, UAE.

Ayban, I. (2011). Foreign Labour in Saudi Arabia and the Negative Impact of Its Presence and the Roles of the Educational Institutions in Reducing Its Hiring to Avoid Those Effects. Psychological and Educational Studies, 6. Shaqra University, Saudi Arabia.

Barnier, M. (2009). Protecting European Consumers and Trademark Owners from Counterfeit Goods -Goods in Transit and Revision of the Community Trade Mark 207/2009 and of the Trade Mark Directive 2008/95/CE. European Commission, 7/March/2013, Belgium.

Belli, G. (2008). No experimental Quantitative Research. Analysis and Interpretation in Nonexperimental Studies (pp. 59-77).

Beshity, I. (2008). Commercial Concealment Grips $40 \%$ of the Services Installations. Al-Riyadh Newspaper, Issue No. (14453), 19th of January, 2008.

Bradley, C. (2014). Anti-Counterfeiting in Saudi Arabia and the UAE. World Trade Mark Review, 
August/September 2014.

Chadha, N. (1999). International Relationships: An Indian Perspective. University of Delhi, Delhi, India.

Chamber of Commerce - Eastern Province - Dammam. (2010). Commercial Concealment and its Impact on the Economic and Social Developments in the Kingdom of Saudi Arabia.

Commuri, S. (2009). The Impact of Counterfeiting on Genuine-Item Consumers' Brand Relationships. Journal of Marketing, 73(May 2009), 86-98. http://dx.doi.org/10.1509/jmkg.73.3.86

Cook, B. G., \& Cook, L. (2008). Nonexperimental quantitative research and its role in guiding instruction. Intervention in School and Clinic, 44(2), 98-104. http://dx.doi.org/10.1177/1053451208321565

Coustasse, A., Arvidson, C., \& Rutsohn, P. (2010). Pharmaceutical Counterfeiting and the RFID Technology Intervention. Journal of Hospital Marketing \& Public Relations, 20(2). http://dx.doi.org/10.1080/15390942.2010.493369

Eccles, L. (2012). Foreign Workers Take Nearly Half of Olympic Park Jobs: So much for Promises to Employ British Staff! Mail Online, 1st of July, 2012, UK.

Editorial. (2015). KSA Ranks 2nd in the World for Remittances. Arab News Saudi online Newspaper. Retrieved on 15th May, 2015 from http://www.arabnews.com/saudi-arabia/news/684651

Ekrami, I. (2016). Are Able to Work and are Not Students or Housewives or Retirees: 55 thousand Saudi Do Not Want to Work. "Statistical Authority". Al-Iqtisadiyyah Newspaper, Issue number 8189, 13th of March, 2016.

Fadel, L. (2016). Britain to Foreign Workers: If You Don't Make \$50,000 A Year, Please Leave! NPR. 3rd of February, 2016.

Fakeeh, M. (2009). Saudization as a Solution for Unemployment: The Case of Jeddah's Western Region. University of Glasgow.

Fenoff, R., \& Wilson, J. (2009). Africa's Counterfeit Pharmaceutical Epidemic: The Road Ahead. October, 2009, (A- CAPPP) Presentation at Michigan State University, USA.

Gharbi, M. (2014). The Negative Repercussions of Foreign Labors on the Gulf Cooperation Council (GCC) and the Policies Adopted to Reduce Them. The Thinkers'Magazine, (10).

Goodman, M. (2015). How to halt the afghan drug trade: Follow the money! Newsweek Magazine, 22nd of March, 2015.

Hair, J. F., Anderson, R. E., Taham, R. L., \& Black, W. C. (1998). Multivariate Data Analysis. London: Prentice Hall.

Hammad, I. (2006). The Criteria for Employment Selection in the Construction Sector. Construction Technology Journal (9th ed.). October 2006, Riyadh, Saudi Arabia.

Handy, C. (1985). Understanding Organization (3rd ed.). London: Penguin Publications.

Iqbal, A. (2011). Creativity and Innovation in Saudi Arabia: An Overview. Innovation: Management, Policy \& Practice, 13.

Johnson, B. (2001). Toward a new classification of nonexperimental quantitative research. Educational Researcher, 30(2), 3-13. http://dx.doi.org/10.3102/0013189X030002003

Kashiwazaki, C. (2002). Japan's Resilient Demand for Foreign Workers. Migration Information Source, 22nd May, 2002, Japan.

Kim, H. (2008). Culture and Social Support. American Psychologist, September 2008, USA. http://dx.doi.org/10.1037/0003-066x

Kingdom of Saudi Arabia Bureau of Experts at the Council of Ministers Official Translation Department, Anti-Concealment Law, Royal Decree No. M/22, 22 June 2004, First Edition 2008.

Kinsawi, M. (2008). A Depiction Presented to Reduce the Phenomenon of Overstayers and Violators of Residency and Employment Laws in the Kingdom of Saudi Arabia. College of Education, Umm Al Qura University, Makkah, Saudi Arabia.

Kirkup, J., \& Dominiczak, P. (2013). Why Hire Foreigners? They Just work Harder. The Telegraph, 5th of November, 2013. UK. 
Mehr, H. (2004). Commercial Concealment and Sheltering in the Islamic Jurisprudence. A PhD Thesis, University of Imam Muhammad bin Saud. Saudi Arabia.

Penz, E. (2005). Forget the "Real" Thing-Take the Copy! An Explanatory Model for the Volitional Purchase of Counterfeit Products. Advances in Consumer Research, 32.

Perry, K. (2015). Drug trafficking costs Britain £10.7 BILLION every year and prices are some of the highest in the world. The Mirror, 17th July 2015.

Petroff, A. (2015). Foreign Students Ditch Dream of Work in UK. CNN Money International, 8th of September, 2015, USA.

PMCE - The Pakistani Muslim Community In England. (2009). Department for Communities and local Government the Change Institute. March, 2009, UK.

Poncha, J. (2014). Lloyds Bank Group Report. Skilled Foreign Workers Boost Economy Says Lloyds Bank. HR Magazine, 1st of September, 2014, UK.

Rabiean, A. (2016). Foreign Labor, We Want It, We Don’t Want It! Al-Hayat Newspaper, 5th of February, 2016, Saudi Arabia.

Ramzi, S. (2013). On the Most Important Issues of the Kuwaiti Economy (Solutions and Recommendations). The Kuwaiti National Assembly, the Secretariat, Research and Information Sector, Studies and Research Management, January 2013.

Rasooldeen, M. (2015a). Female Expat Arrested for Commercial Concealment. Arab News Newspaper, 30th December, 2015. Saudi Arabia.

Rasooldeen, M. (2015b). Arab Expat Running 10 Shops Nabbed Under Anti-Fraud L. Arab News Newspaper. 19th November, 2015, Saudi Arabia.

Rasooldeen, M. (2015c). Expat Running a Dental Lab Arrested. Arab News Newspaper, 13th of September, 2015, Saudi Arabia.

Robins, P. (2014). Narcotic Drugs in Dubai Lurking in the Shadow. British Journal of Middle East Studies, 41(2), 2014. http://dx.doi.org/10.1080/13530194.2014.878502

Sabry, A. (2015). Foreigners in Great Britain Have Better Chances of Employment than British Citizens Themselves. The Seventh Day Newspaper, 4th of July, 2015.

The Saudi Ministry of Commerce and Industry. (2015). Commercial Concealment and its Impact on Small and Medium Size Businesses and the Saudi Economy. 10th of November, 2015.

Wertheimer, A., \& Santella, T. (2005). Counterfeit Drugs: Defining the Problem and Finding Solutions. Expert Opinion on Drug Safety, 4(4), 2005. http://dx.doi.org/10.1517/14740338.4.4.619

\section{Copyrights}

Copyright for this article is retained by the author(s), with first publication rights granted to the journal.

This is an open-access article distributed under the terms and conditions of the Creative Commons Attribution license (http://creativecommons.org/licenses/by/3.0/). 